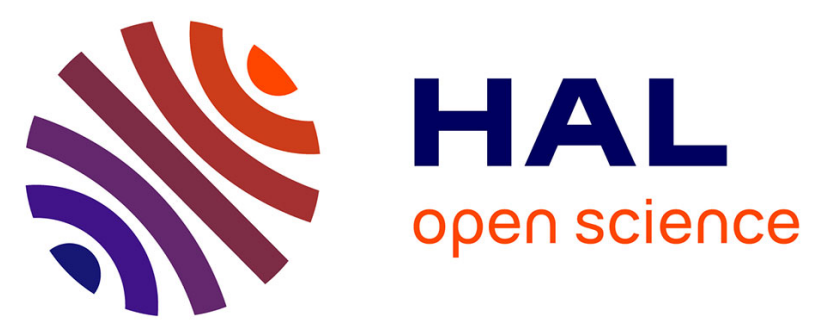

\title{
The brain H3-receptor as a novel therapeutic target for vigilance and sleep-wake disorders.
}

Régis Parmentier, Christelle Anaclet, Christian Guhennec, Emmanuel Brousseau, Denis Bricout, Thierry Giboulot, Donna Bozyczko-Coyne, Karine Spiegel, Hiroshi Ohtsu, Michael Williams, et al.

\section{To cite this version:}

Régis Parmentier, Christelle Anaclet, Christian Guhennec, Emmanuel Brousseau, Denis Bricout, et al.. The brain H3-receptor as a novel therapeutic target for vigilance and sleep-wake disorders.. Biochemical Pharmacology, 2007, 73 (8), pp.1157-71. 10.1016/j.bcp.2007.01.002 . inserm-00150083

\section{HAL Id: inserm-00150083 https://www.hal.inserm.fr/inserm-00150083}

Submitted on 9 Aug 2007

HAL is a multi-disciplinary open access archive for the deposit and dissemination of scientific research documents, whether they are published or not. The documents may come from teaching and research institutions in France or abroad, or from public or private research centers.
L'archive ouverte pluridisciplinaire HAL, est destinée au dépôt et à la diffusion de documents scientifiques de niveau recherche, publiés ou non, émanant des établissements d'enseignement et de recherche français ou étrangers, des laboratoires publics ou privés. 
Revised \#3 11/21/06

Abstract: 240 words

Pages: 15

Figures: 7

Tables: 3

\title{
The brain $\mathrm{H}_{3}$-receptor as a novel therapeutic target for vigilance and sleep- wake disorders
}

\author{
R Parmentier ${ }^{1,2,3}$, C Anaclet $^{1,2}$, C Guhennec $^{3}$, E Brousseau $^{3}$, D Bricout ${ }^{3}$, \\ T. Giboulot ${ }^{3}$, D Bozyczko-Coyne ${ }^{4}, K^{2}$. Spiegel ${ }^{1}, \mathrm{H} \mathrm{Ohtsu}^{5}, \mathrm{M} \mathrm{Williams}^{4}$ and JS Lin ${ }^{1,2}$ \\ ${ }^{1}$ INSERM-U628, Integrated Physiology of Brain Arousal Systems, 69373 Lyon, France; \\ ${ }^{2}$ Department of Experimental Medicine, Faculty of Medicine, Claude Bernard University, 69373 Lyon, \\ France. \\ Worldwide Discovery Research, Cephalon, Inc., \\ ${ }^{3} 94700$ Maisons-Alfort, France; ${ }^{4}$ West Chester, PA 19380-4245, U.S.A. and \\ ${ }^{5}$ Department of Cellular Pharmacology, Tohoku University, School of Medicine, \\ Sendai 980-8575, Japan
}

\section{Correspondence:}

Jian-Sheng Lin, D.Sc., MD.

INSERM-U628,

Département de Médecine Expérimentale,

Faculté de Médecine, Université Claude Bernard,

8 avenue Rockefeller,

69373 Lyon Cedex 08, France.

Phone: (33) 478777116

Fax: (33) 478777150

Email: lin@univ-lyon1.fr

Key words: Sleep-wake cycle, histamine, $\mathrm{H}_{3}$-receptor, cortical EEG, arousal, vigilance, sleep-wake disorders, Narcolepsy, Somnolence, modafinil, psychostimulant, knockout mice,

Running Title: $\mathrm{H}_{3}$-receptors as therapeutic targets for sleep-wake disorders.

Abbreviations : HA, histamine; HDC, histidine decarboxylase; KO, knockout; PS, paradoxical sleep; $\mathrm{RH}_{3}$ agonist, $\mathrm{H}_{3}$-receptor agonist; $\mathrm{RH}_{3}$-antagonist, $\mathrm{H}_{3}$-receptor antagonist/inverse agonist; $\mathrm{SWS}$, slow wave sleep W, wakefulness or waking; WT, wild type. 


\begin{abstract}
Brain histaminergic neurons play a prominent role in arousal and maintenance of wakefulness (W). $\mathrm{H}_{3^{-}}$ receptors control the activity of histaminergic neurons through presynaptic autoinhibition. The role of $\mathrm{H}_{3}$ receptor antagonists/inverse agonists $\left(\mathrm{H}_{3} \mathrm{R}\right.$-antagonists) in the potential therapy of vigilance deficiency and sleep-wake disorders were studied by assessing their effects on the mouse cortical-EEG and sleep-wake cycle in comparison to modafinil and classical psychostimulants. The $\mathrm{H}_{3} \mathrm{R}$-antagonists, thioperamide and ciproxifan increased $\mathrm{W}$ and cortical-EEG fast rhythms and, like modafinil, but unlike amphetamine and caffeine, their waking effects were not accompanied by sleep rebound. Conversely, imetit $\left(\mathrm{H}_{3} \mathrm{R}\right.$-agonist) enhanced slow wave sleep and dose-dependently attenuated ciproxifan-induced W, indicating that the effects of both ligands involve $\mathrm{H}_{3}$-receptor mechanisms. Additional studies using knockout (KO)-mice confirmed the essential role of $\mathrm{H}_{3}$-receptors and histamine-mediated transmission in the wake properties of $\mathrm{H}_{3} \mathrm{R}$ antagonists. Thus ciproxifan produced no increase in $\mathrm{W}$ in either histidine-decarboxylase (HDC, histaminesynthesizing enzyme) or $\mathrm{H}_{1}$ - or $\mathrm{H}_{3}$-receptor $\mathrm{KO}$-mice whereas its waking effects persisted in $\mathrm{H}_{2}$-receptor $\mathrm{KO}$ mice. These data validate the hypothesis that $\mathrm{H}_{3} \mathrm{R}$-antagonists, through disinhibition of $\mathrm{H}_{3}$-autoreceptors, enhancing synaptic histamine that in turn activates postsynaptic $\mathrm{H}_{1}$-receptors promoting $\mathrm{W}$. Interestingly amphetamine and modafinil, despite their potent arousal effects, appear unlikely to depend on histaminergic mechanism as their effects still occurred in HDC KO-mice. The present study thus distinguishes two classes of wake-improving agents: the first acting through non-histaminergic mechanisms and the second acting via histamine and supports brain $\mathrm{H}_{3}$-receptors as potentially novel therapeutic targets for vigilance and sleepwake disorders.
\end{abstract}




\section{Introduction}

The functional importance of histamine (HA) in sleep-wake regulation dates back to the 1930s when the prototypical anti-histamine drugs were discovered. Now identified as $\mathrm{H}_{1}$-receptor antagonists, the use of this class of drugs in the treatment of allergic diseases is frequently associated with sedation, drowsiness and slowed reaction time in humans. With the discovery, in the early 1980s, that histamine is a central neurotransmitter [1-3], it was hypothesized that blockade of histamine-mediated transmission could be responsible for these side-effects. Recent experimental data support the hypothesis that histaminergic neurons constitute a major wake-promoting system [4] within the brain arousal networks [5-9].

Histaminergic perikarya occur exclusively in the tuberomammillary nucleus (TMn) and adjacent areas of the posterior hypothalamus [10-13], a heterogeneous area crucial for waking as its destruction or inactivation induces hypersomnia [4-6]. TM neurons send inputs to various brain regions, notably those that control the sleep-wake cycle, such as the cortex, thalamus, preoptic and anterior hypothalamus, brainstem and forebrain cholinergic and monoaminergic structures [2-4; 10-13]. Identified histaminergic neurons in the mouse [14] as well as presumed histaminergic cells in the cat [6;15], discharge tonically and specifically during wakefulness; this pattern of activity being the most wake-selective pattern identified in the brain to date. Histaminergic neurons stimulate or facilitate large brain areas through postsynaptic $H_{1}$ and $H_{2}$ receptors [2;3], thus contributing to cortical activation [4]. Indeed, treatments that impair HA-mediated neurotransmission, e.g., blockade of HA synthesis or postsynaptic $\mathrm{H}_{1}$ receptors, increase cortical slow waves and enhance sleep. In contrast, enhancement of histaminergic neurotransmission promotes waking $[4 ; 13$; 16; 17]. Finally, Long-term abolition of HA synthesis in knockout (KO) mice impairs the cortical electroencephalogram (EEG) and has deleterious effect on both sleep and wake quality, thus causing permanent somnolence and behavioral deficits. Consequently, mice that lack brain HA are unable to remain awake when high vigilance is required, e.g. at lights off or placed in a new environment [16]. Together, these results indicate that HA-containing neurons have a key role in maintaining the brain awake under normal conditions and in the presence of behavioral challenges.

Since $\mathrm{H}_{3}$-receptors control the release, synthesis and turnover of $\mathrm{HA}$ and the neuronal activity of histaminergic cells $[15 ; 18 ; 19]$, it was hypothesized that the cortical activity and sleep-wake cycle could be modulated through $\mathrm{H}_{3}$-receptor and consequently their ligands [20]. Consistent with this assumption, early studies in cats showed that sleep increased or decreased following, respectively, administration of $\mathrm{H}_{3^{-}}$ receptor agonists or antagonist/inverse agonists. Thioperamide, an imidazole $\mathrm{H}_{3} \mathrm{R}$-antagonist, promoted cortical activation and waking while $\alpha$-methylhistamine, a chiral $\mathrm{H}_{3} \mathrm{R}$-agonist and BP2-94, another $\mathrm{H}_{3}$-receptor agonist, enhanced cortical slow activity and increased slow wave sleep $[4 ; 20]$. Similar results were obtained using $\mathrm{H}_{3} \mathrm{R}$-agonists or antagonists in mice, rats and guinea pigs [16;21;22], although the effect of $\mathrm{H}_{3} \mathrm{R}$ agonists appeared to be compound- and species- dependent [23; 24].

The robust effects of $\mathrm{H}_{3}$-receptor ligands in sleep-wake control in animals supports a potential role in treating human sleep-wake disorders, notably the use of $\mathrm{H}_{3} \mathrm{R}$-antagonists to improve somnolence and vigilance deficiency of diverse pathophysiological origin. However, several important fundamental questions arise as regards to the characterization of their effects. For example, what are their effects on sleep-wake 
parameters as compared to those induced by the current wake-promoting compound modafinil [25-28] or classical psychostimulants? Is their waking effect mediated specifically by $\mathrm{H}_{3}$-receptors and through HAmediated neurotransmission? The latter question is particularly important as $\mathrm{H}_{3}$-receptors also function as heteroreceptors that control the release and synthesis of other neurotransmitters in addition to HA including acetylcholine, dopamine, norepinephrine, serotonin and galanin [3; 29], also involved in sleep-wake control [7-9].

In the present study, therefore, the effects of the $\mathrm{H}_{3} \mathrm{R}$-antagonists, thioperamide and ciproxifan, were studied on the cortical EEG and sleep-wake cycle in mouse, a species in which the effects of $\mathrm{H}_{3} \mathrm{R}$-ligands are less well documented, but of great interest in basic and preclinical investigations particularly because of increasing use of knockout $(\mathrm{KO})$ models. The waking effects of $\mathrm{H}_{3} \mathrm{R}$-antagonists were compared with those induced by the atypical stimulant, modafinil and the classical psychostimulants, amphetamine and caffeine. Additionally, the pharmacological profile of ciproxifan was evaluated using pharmacological antagonism with the $\mathrm{H}_{3} \mathrm{R}$-agonist, imetit and in several $\mathrm{KO}$ mouse models in which HA-mediated neurotransmission was altered either in terms of synthesis or receptors.

2. Effects of modafinil, psychostimulants and $\mathrm{H}_{3}$-receptor antagonists on the mouse cortical EEG and sleep-wake cycle.

To compare the wake promoting effects of $\mathrm{H}_{3} \mathrm{R}$-antagonists in comparison to modafinil and classical psychostimulants, C57/Black6/J genetic background mice $(n=22$, Charles River, France) were implanted with electrodes to monitor the cortical EEG and sleep-wake cycle according to previously described methods [16]. Briefly, All mouse strains used in this study were housed individually in transparent barrels $(\phi 20 \mathrm{~cm}$, height $30 \mathrm{~cm}$ ) in an insulated sound-proofed recording room maintained at an ambient temperature of $22 \pm$ $1^{\circ} \mathrm{C}$ and on a $12 \mathrm{~h}$ light/dark cycle (lights-on at $7 \mathrm{~h} 00$ ), food and water being available ad libitum. Polygraphic recordings were performed after administration of placebo or the drugs and scored as described [16] by 30s epochs for wakefulness (W), slow wave sleep and paradoxical (PS or REM) sleep. Cortical EEG power spectra were analyzed for consecutive $30-\mathrm{sec}$ epochs within the frequency range of $0.4-60 \mathrm{~Hz}$ using a fast Fourier transformation routine by the CED-spike 2 analysis system. Statistical evaluation was performed using ANOVA followed by Dunnett's $t$ test. Each animal served as its own control.

D-amphetamine (1, 4 and $8 \mathrm{mg} / \mathrm{kg}$, Sigma, St. Louis, MO USA), caffeine (10, 30 and $100 \mathrm{mg} / \mathrm{kg}$, Sigma), modafinil (10, 30 and $100 \mathrm{mg} / \mathrm{kg}$, Cephalon, France), thioperamide (10, 30 and $100 \mathrm{mg} / \mathrm{kg}$, Sigma) and ciproxifan (1, 3 and $10 \mathrm{mg} / \mathrm{kg}$, Sigma) were administered i.p. at the light phase (11h30) when the animals slept most of the time at baseline (defined as sleeping period). As shown in Table 1 and Figures 1 and 2, all compounds at the doses used increased the time spent awake. The wake effect, occurring as early as the first hour after dosing, was accompanied by delayed sleep latencies (Table 1; Figures 1 and 2), the duration of the effect on waking being dose-dependant. The increase in wakefulness was at the expense of both slow wave sleep (SWS) and paradoxical sleep (PS). Compared with modafinil and psychostimulants, the effects of the two $\mathrm{H}_{3} \mathrm{R}$-antagonists had several characteristics: 


\subsection{Prompt awakening effect}

The waking effect of $\mathrm{H}_{3} \mathrm{R}$-antagonists occurred quickly in the mouse and was promptly terminated, similar to that seen in the cat $[4 ; 20 ; 30]$. At a dose 10 -fold higher than the minimally effective one, the waking effect was prolonged to two more hours whereas at an 8-10 fold higher dose, the waking effect of modafinil, amphetamine and caffeine produced additional periods of 3, 4 and more than $7 \mathrm{~h}$ respectively (Figure 2 ). In addition to the bioavailability of $\mathrm{H}_{3} \mathrm{R}$-antagonists, their short-lasting effect probably reflects the fact that the $\mathrm{HA}$ released by $\mathrm{H}_{3} \mathrm{R}$-antagonists is rapidly eliminated and that there are no known transporter mechanisms involved in HA catabolism that could be affected by $\mathrm{H}_{3} \mathrm{R}$-antagonists. Indeed, released HA is instantly inactivated by the enzyme, histamine- $\mathrm{N}$-methyltransferase. HA is also known to have a faster turnover rate than other neurotransmitters with the exception of acetylcholine [1;29]. $\mathrm{H}_{3} R$-antagonists (e.g. ciproxifan) also have no interactions with monoamine transporters [data not shown]. In contrast, the psychostimulant effects of amphetamine depend on an inhibition of the dopamine transporter (DAT) in addition to an enhancement of monoamine release and blockade of monoamine oxidase activity. Modafinil binds with moderate affinity to DAT ( 4-7 $\mu \mathrm{M})$ [31-33]. However, the dopaminergic mechanisms involved in the waking effect of modafinil may be relatively pronounced in the mouse [32] compared with other experimental species. The relative short lasting effect of $\mathrm{H}_{3} \mathrm{R}$-antagonists demonstrated here, if extrapolatable to humans, may be an advantage for their potential therapeutic use, i.e. maintaining daytime wakefulness, followed by normal nocturnal sleep.

\subsection{Quiet and alert waking}

In mice as in other species, psychostimulants such as amphetamine and caffeine markedly increased behavioral activity and locomotion in addition to EEG arousal, whereas no overt behavioral excitation occurs during wakefulness following modafinil, thioperamide and ciproxifan. Animals were quiescent for the majority of time presenting a level of activity similar to waking seen during baseline recording. The most notable difference seen in this study between $\mathrm{H}_{3} \mathrm{R}$-antagonists and other wake-promoting agents involved the qualitative aspect of waking, i.e., cortical EEG. Whereas all the compounds used caused a clear suppression of cortical slow waves ( $\delta$ and slow $\theta$ bands, mainly $0.8-5 \mathrm{~Hz}$ ), $\mathrm{H}_{3} \mathrm{R}$-antagonists like ciproxifan were distinct from other compounds due to their effect on cortical fast rhythms ( $\beta$ and $\gamma$ bands, 20-60 Hz). Thus, amphetamine and modafinil enhanced waking behavior without increasing cortical fast activity. Conversely, the "quiet" waking induced by ciproxifan was accompanied by a marked enhancement in cortical fast rhythms (Figure 1). Thus, the mean total power of cortical fast rhythms $(20-60 \mathrm{~Hz})$ during waking after ciproxifan dosing is increased by $9 \pm 2 \%$ ( $p<0.05$, ANOVA) compared with that seen after placebo in the same mice $(n=7$, data obtained from 120 consecutive samples of 30 s wake episodes after placebo or ciproxifan dosing in each mouse). Similar results have been obtained in the cat [4; 30 and data not shown].

The marked wake-improving effect of ciproxifan demonstrated in several species is consistent with the concept of a predominant role of histaminergic neurons in cortical activation during waking. Because the occurrence of cortical fast rhythms is closely associated with the so-called higher mental activities, e.g., attention, alertness, and leaning, these results thus indicate that waking elicited by $\mathrm{H}_{3} \mathrm{R}$-antagonists is of a high level of vigilance and that the histaminergic system plays a role not only in waking, the basis for all other high brain functions, but also in some cognitive processes. These data also suggest that clinically suitable 
$\mathrm{H}_{3} \mathrm{R}$-antagonists might be designated as a therapeutic approach for vigilance disorders associated with cognitive deficiency $[4 ; 20 ; 30,34]$. Finally, ciproxifan, through activation of histamine neurons as demonstrated by their dense c-fos expression after dosing, restored a sustained cortical activation in comatose or hypersomniac cats after acute or chronic brainstem transection, respectively [4]. This clear arousing effect suggests that drug-like $\mathrm{H}_{3} \mathrm{R}$-antagonists may have the ability to restore cortical activation in comatose or brain-traumatized patients.

\subsection{Absence of sleep rebound}

The long lasting waking elicited by amphetamine and caffeine, but not that induced by modafinil, was followed by a significant sleep rebound, mainly consisting of slow wave sleep (Tables 2 and 3) and by an increase in power spectral density of cortical slow activity (data not shown). These data are in agreement with those previously obtained in the cat $[35 ; 36]$ and rat $[37 ; 38]$. Like modafinil, but unlike amphetamine or caffeine, the waking effects of thioperamide and ciproxifan were followed by a sleep-wake cycle with an amount of both slow wave sleep and paradoxical sleep similar to that seen during baseline recording, indicating no significant sleep rebound. The significance of the different effects of the studied agents on subsequent sleep remains unclear as the mechanisms and functions of sleep rebound are far from well understood. It has previously speculated that an overuse or exhaustion of catecholamines, such as the enhanced prolonged release associated with the use of amphetamine (but presumably not with that of modafinil), may be one cause of sleep rebound following the amphetamine-induced arousal and behavioral excitation [36]. One function of sleep rebound would, therefore, be to restore the physiological and functional levels of catecholaminergic neurons after over activity and also to allow the brain to recover from the deleterious effects of catecholamine systems during sustained waking. In support of this assumption, one of the few genes in the rat brain which is significantly induced and proportionally expressed after sleep deprivation is that of arylsulfotransferase, a final enzyme responsible for the catabolism of catecholamines in rodents [39; 40]. Thus the absence of sleep rebound associated with modafinil could also be interpreted as absence of catecholamine exhaustion as the waking effect of modafinil does not seem to depend on endogenous catecholamines [35]. Moreover, no signs of direct neuronal depolarization/excitation on target cells have been reported for modafinil, even though diffuse expression of immediate early gene c-fos [41], or enhanced histamine release [42] occurred with high doses of modafinil. These effects can be attributed to a direct consequence of the sustained waking induced by modafinil rather than a direct pharmacological targeted action per se. Indeed, c-fos expression is a state-dependent phenomenon, occurring most densely in large brain areas after spontaneous or induced wakefulness [43-45]. Alternatively, one of the major effects of modafinil is the induction of a marked decrease in GABA outflow in the critical brain regions involved in sleep-wake control including the posterior hypothalamus and preoptic area [46, 47]. Wakefulness seen with modafinil could then result from a disinhibition of brain arousal systems, e.g., the HA and orexin containing cells in the posterior hypothalamus known for their crucial role in the maintenance of waking [4-6; 9]. A quiet waking state resulting from this disinhibitory mechanism would therefore have a different effect on the subsequent sleep rebound to that seen with amphetamine. 
The reasons why $\mathrm{H}_{3} \mathrm{R}$-antagonist-induced waking is not associated with a sleep rebound remain to be determined. In any proposed hypothesis, the above-mentioned associated characteristics, including quiet waking, prompt and short-lasting effect, rapid HA turnover, the lack of an overuse of catecholamines and the lack of potent interactions with monoamine transporters may be contributory. Whatever these underlying mechanisms might be, the absence of sleep rebound observed with modafinil and $\mathrm{H}_{3} \mathrm{R}$-antagonists, is critical in the clinical setting in terms of quality of life outcomes.

3. Effects of the $\mathrm{H}_{3}$-receptor agonist, imetit on the mouse cortical EEG and sleep-wake cycle and ciproxifan-induced waking

From this and other studies, it is clearly established that $\mathrm{H}_{3} \mathrm{R}$-antagonists promote waking and improve vigilance. An important corollary question is whether $\mathrm{H}_{3} \mathrm{R}$-agonists induce or facilitate sleep. It was also important to verify if the waking effect of $\mathrm{H}_{3} R$-antagonists could be reversed by $\mathrm{H}_{3} R$-agonists. To this aim, the effects of imetit (a potent and selective $\mathrm{H}_{3} R$-agonist) were examined in the same mouse model $(n=8)$ during lights-off phase, when the animals spent most of the time awake at baseline (defined as the waking period).

When administered alone before lights-off, imetit (1, 3 or $10 \mathrm{mg} / \mathrm{kg}$ i.p.) decreased cortical fast rhythms and markedly increased the power spectral density of the neocortical slow activity $(\delta+\theta$ ranges, mainly $0.8-5 \mathrm{~Hz}$, Figure 3 ) and spindles (8-15 Hz, not shown), resulting in a state of high voltage electrical activity (Figure 3). The effects on the cortical EEG were manifested on a $4 \mathrm{~h}$ polygraphic recording as an increase in slow wave sleep and decrease in wake duration. Paradoxical sleep decreased slightly at all doses without reaching statistical significance (Figures 3,5). Such effects were detectable at a dose of $1 \mathrm{mg} / \mathrm{kg}$ (although insignificant over the $4 \mathrm{~h}$ analyzed period) and increased at 3 and $10 \mathrm{mg} / \mathrm{kg}$ (Figures 3, 5). The data are consistent with those obtained in the cat using $\alpha$-methylhistamine, a chiral $\mathrm{H}_{3} \mathrm{R}$-agonist [20]. These effects of imetit in the mouse were similar to those seen with BP2-94, another $\mathrm{H}_{3}$-receptor agonist that in the cat induced a dramatic increase in the power spectral density of cortical slow activity, associated with a significant increase in slow wave sleep [4], a phenomenon similar to that seen during the recovery phase from sleep deprivation. $\mathrm{H}_{3}$-receptor agonists might therefore have beneficial effects, helping the brain to recover from fatigue, mental exhaustion or sleep deprivation due to diverse causes. They might also be potentially superior to the classical antihistamines, the $\mathrm{H}_{1}$-receptor antagonists and other classes of hypnotics that induce slow wave sleep associated with prominent paradoxical sleep reduction, incompatible with physiological sleep, as their effect on paradoxical sleep might not occur or could be less prominent. Clinically suitable $\mathrm{H}_{3} \mathrm{R}$-agonists might thus be expected to improve qualitative and quantitative aspects of sleep in some types of insomnia, e.g., those resulting from anxiety, stress or neuropathology.

The arousal effects of ciproxifan ( $3 \mathrm{mg} / \mathrm{kg}$, i.p.) observed during the sleep period were dosedependently antagonized by the $\mathrm{H}_{3}$-receptor agonist, imetit $(1,3$ and $10 \mathrm{mg} / \mathrm{kg}, \mathrm{i} . \mathrm{p} . \mathrm{n}=8$; Figures 4,5$)$ with a significant reduction of induced-waking occurring after $3 \mathrm{mg} / \mathrm{kg}$ imetit with wake and slow wave sleep duration returning to near control at $10 \mathrm{mg} / \mathrm{kg}$ dosing. Paradoxical sleep however, remained decreased after imetit treatment (Figure 4). The delayed latency to slow wave sleep due to ciproxifan was reversed at $10 \mathrm{mg} / \mathrm{kg}$ whereas latency to paradoxical sleep was unchanged after all imetit doses (Figure 4). These data are consistent with those from cats showing an antagonism of the waking effect of thioperamide by $\alpha$ - 
methylhistamine [20] supporting the concept of an $\mathrm{H}_{3}$ receptor-dependent mechanism for their effects on EEG and sleep-wake parameters. However, it remains to be understood why imetit and other $\mathrm{H}_{3} \mathrm{R}$-agonists do not increase paradoxical sleep, as they do slow wave sleep, since a possible paradoxical sleep-permissive role of histamine neurons has been hypothesized in the mouse. This is based on a paradoxical sleep-off discharge pattern of HA-containing cells [14], on the one hand; and on the other hand, an increase in paradoxical sleep seen with acute or chronic suppression of histidine decarboxylase (HDC) using either the HDC inhibitor, $\alpha$-fluoromethylhistidine or HDC KO mice [16]. In addition, both imetit and ciproxifan caused a slight decrease in paradoxical sleep (Figure 5), making it possible that targets other than $\mathrm{H}_{3}$-receptors or $\mathrm{HA}$ transmission may be involved or reflecting the inverse agonist profiles of these two compounds. Additional experiments are therefore necessary.

\section{Characterization of the wake-promoting agents with reference to histamine-mediated transmission using knockout mouse models}

As HA neurons are thought to play a crucial role in maintaining cortical activation and waking, one may ask whether modafinil induces sustained wakefulness via activation of histaminergic neurons. The same question may be addressed regarding psychostimulants even though a predominant dopaminergic mechanism exists. The question has become more intriguing since reports in the rat of a c-fos expression in histaminergic tuberomammillary nucleus [41] and an increase in hypothalamic HA outflow [42], both seen with large doses of modafinil. In regard to $\mathrm{H}_{3} \mathrm{R}$-antagonists, one may also question the importance of histamine transmission in their arousal effects and if there is an involvement of other neurotransmitters also involved in waking [8; 9] and controlled by $\mathrm{H}_{3}$-receptors. To test the histaminergic hypothesis regarding the mechanisms of action of amphetamine, modafinil and ciproxifan in waking, their effects in KO mouse models in which histamine-mediated transmission is altered, e.g., $\mathrm{HDC}$ and $\mathrm{H}_{1}-, \mathrm{H}_{2}$ - and $\mathrm{H}_{3}$ - receptor $\mathrm{KO}$ mice was studied. As previously reported, these KO mice are able to maintain, under the basal non-challenged conditions and despite qualitative change, a daily amount of waking near to that of wild type (WT) mice [16; 48-50], probably due to the compensatory mechanisms elaborated by brain plasticity.

A group ( $n=9$ ) of $129 \mathrm{~Sv}$ genetic-background inbred WT and HDC KO mice were recorded simultaneously, as previously described, to compare the sleep-wake effects of the W-promoting agents given i.p. during the light phase [16]. These mice were generated according to procedures previously described [51] and their genotypes confirmed using PCR. The doses used for amphetamine, modafinil and ciproxifan were 1, 32 and $1 \mathrm{mg} / \mathrm{kg}$ respectively as these approximated equal potency in terms of wake induction. As presented above, all agents at the indicated doses caused, in all WT models (129Sv as well as C57/Black6/J genetic background), increased waking at the expense of slow wave sleep and paradoxical sleep as compared with placebo (Figures 6, 7; Table 3).

In the HDC-KO mice, the same amphetamine and modafinil doses increased waking and decreased slow wave sleep and paradoxical sleep during the sleeping phase, the effect being identical or slightly superior to that seen in WT animals. In contrast, the same ciproxifan dosing (or higher doses up to $10 \mathrm{mg} / \mathrm{kg}$, data not shown) had no effect on either the cortical EEG or the sleep-wake states (Figures 6, 7; Table 3). 
HDC-KO mice lack endogenous HA synthesis and HA-containing neurons in the brain [16; 51]. The present data thus indicate that the sleep-wake effects of ciproxifan, but not those of amphetamine or modafinil, depend on histamine-mediated transmission. However, these data do not appear to support a direct excitation of histamine neurons in the mechanism of action of modafinil or amphetamine-like psychostimulants. C-fos expression in the histaminergic tuberomammillary nucleus and diffuse brain areas [41] or the HA release [42] seen in the rat after large doses of modafinil is thus likely to be the consequence of sustained waking rather than a modafinil-mediated excitation, as both c-fos expression and histamine release are positively correlated to waking [43-45;52]. Using c-fos as a marker in the cat supports this hypothesis. Indeed, examination of c-fos labeling after modafinil dosing but before an established long duration wake state revealed sparse c-fos expression in the histaminergic tuberomammillary nucleus and other brain regions [53]. Additionally in either normal [15] or brainstem-transectioned [4] cats, expression of cfos in histamine neurons has only been seen with ciproxifan and not with other waking substances including modafinil, as already mentioned, and psychostimulants like amphetamine and methylphenidate [53], indicating that only stimuli specific to the histaminergic system may induce c-fos expression within histaminergic cell bodies. However, it cannot be excluded that histaminergic neurons may be indirectly involved in modafinil-induced waking, as a significant decrease in GABA outflow in the posterior hypothalamus is seen in vivo after modafinil dosing [46; 47] and so HA or orexin neurons located in this region could be disinhibited and so enhance waking.

Since only ciproxifan-mediated arousal depends on HA, this compound was further characterized using C57/Black6/J background KO mice devoid of $\mathrm{H}_{1^{-}}(n=8)$, or $\mathrm{H}_{2^{-}}(n=8)$ or $\mathrm{H}_{3^{-}}(n=12)$ receptors. These mouse genotypes were generated respectively according to the previously described procedures and both WT and KO littermates were identified using PCR [54-56].

Ciproxifan (1 mg/kg, i.p.) increased waking (+50-86\% over a $4 \mathrm{~h}$ recording) and cortical fast rhythms in all WT mouse groups during the sleeping period, whereas it had no effect in either $\mathrm{H}_{1}$ - or $\mathrm{H}_{3}$-receptor $\mathrm{KO}$ littermates. Interestingly, the effects of ciproxifan on the cortical EEG and waking were intact in $\mathrm{H}_{2}$-receptor KO-mice, the increase in waking being similar in $\mathrm{KO}(+93 \%$ over $4 \mathrm{~h})$ than WT littermates (+85\%) (Table 3$)$. These data confirm the pharmacological selectivity of ciproxifan for $\mathrm{H}_{3}$-receptors already demonstrated with imetit and the essential role of the $\mathrm{H}_{3}$-receptor in its arousal effect. Although recent studies indicate that both ciproxifan and imetit may process weak activity at $\mathrm{H}_{4}$-receptors $[34 ; 57 ; 58]$ and although $\mathrm{H}_{3}$-receptors also regulate the availability of neurotransmitters other than $\mathrm{HA}$, e.g., norepinephrine, acetylcholine and $5 \mathrm{HT}$, that are also involved in sleep-wake control, the results generated from $\mathrm{KO}$ mice indicated that the effect of ciproxifan on EEG and sleep-wake parameters selectively depend on $\mathrm{H}_{3}$-receptor and histamine-mediated transmission. The fact that the waking effect of ciproxifan was observed in the $\mathrm{H}_{2}$-receptor $\mathrm{KO}$ mouse but absent in the $\mathrm{H}_{1}$-receptor $\mathrm{KO}$ genotype [48] confirms the dominant, if not exclusive, importance of $\mathrm{H}_{1}$ receptors in the postsynaptic mechanisms of histaminergic arousal. Together, these data validate the earlier hypothesis $\left[4 ; 20\right.$ ] that $\mathrm{H}_{3} \mathrm{R}$-antagonists, via dis-autoinhibition of presynaptic $\mathrm{H}_{3}$-receptors, enhance the turnover and activity of histaminergic neurons, increasing synaptic HA that in turn activates postsynaptic $\mathrm{H}_{1}$ receptors, promoting wakefulness and improving vigilance. 


\section{Conclusions}

Sleep-wake disorders constitute a major challenge of public health due to their high prevalence (19$37 \%$ ) in the general population. Somnolence is associated with various pathological conditions including sleep apnea, excessive daytime sleepiness due to nocturnal insomnia, Parkinson's disease and narcolepsy or circumstances related to lifestyle, including daytime sleepiness due to voluntary sleep restriction or sleep deprivation resulting from night shift work, overwork or jet-lag. Novel, safe, efficacious and more specific therapeutic approaches are, therefore, in great demand in sleep medicine.

The present study has distinguished two classes of wake-promoting agents: those involving histamine and those that appear histamine-independent and supports the role of the brain $\mathrm{H}_{3}$-receptors as potentially novel therapeutic targets for vigilance and sleep-wake disorders. Compared to current wakepromoting medications, $\mathrm{H}_{3} \mathrm{R}$-antagonists appear to possess several advantageous characteristics that might favor their development as novel therapeutics for the treatment of sleep-wake disorders especially somnolence:

5.1. A well-defined mechanism of action, that is based on a clearly defined molecular target and the wellestablished role of $\mathrm{HA}$ neurons and the role of $\mathrm{H}_{3}$-receptors in sleep wake mechanisms.

5.2. A more specified treatment. HA plays a key role in somnolence. Thus mice that lack HA are permanently somnolent [16] and narcoleptic dogs are HA deficient [59]. Moreover, narcoleptic patients have decreased HA levels in the CSF [60].

\subsection{Simultaneous cognitive improvement. $\quad \mathrm{H}_{3} \mathrm{R}$-antagonists may improve cognition either via promoting EEG} activation and vigilance or by improvement of specific cognitive processes (e.g., learning and memory) via cholinergic or noradrenergic systems that are also regulated by $\mathrm{H}_{3}$-receptors [30; 61-63].

\subsection{A unique approach against narcolepsy. Finally, $\mathrm{H}_{3} \mathrm{R}$-antagonists may represent a unique} pharmacotherapy for the treatment of narcolepsy. In addition to their specific effects on the excessive somnolence, they may be also anticipated to inhibit or suppress narcoleptic attacks (direct onset of paradoxical sleep from waking or sleep onset REM periods called by some authors), an effect related to the permissive role exerted by histaminergic and other monoaminergic cells on paradoxical sleep. Indeed, HA cells in mice [14] and cats [6; 15] exhibit paradoxical sleep-off activity and acute or chronic abolition of HA synthesis results in an increase in paradoxical sleep [16]. Thus, enhancement of histaminergic neuronal activity by $\mathrm{H}_{3} \mathrm{R}$-antagonists is anticipated to prevent the occurrence of paradoxical sleep and accordingly narcoleptic attacks in patients. Additionally, $\mathrm{H}_{3} \mathrm{R}$-antagonists are effective in treating cataplexy in a dog narcoleptic model [64]. The development of novel and selective $\mathrm{H}_{3} \mathrm{R}$-antagonists may thus lead to new therapies to treat the complex phenomenon of narcolepsy and other human sleep-wake disorders.

\section{Acknowledgments}

The authors wish to thank Colette Buda, Jean-Pierre Sastre and Gerard Guidon for their experimental and technical contributions, $\mathrm{Pr} \mathrm{H}$. Watanabe (Kyushu Univ. Fukuka, Japan) for providing the $\mathrm{H}_{1}$ - and $\mathrm{H}_{2}$-receptor knockout mouse strains and Dr. H. Kotani (Banyu Pharmaceutical Co. Ltd, Japan) for providing the $\mathrm{H}_{3}$ receptor knockout mouse strain and Dr. J.M. Lecomte (Bioprojet, Paris, France) for the kind gift of ciproxifan to JSL This work was supported by 1) INSERM U52, U480 and U628, Lyon, France; 2) Faculty of Medicine, 
Claude Bernard University, Lyon, France; 3) European Community, Fifth Framework Program Grant QLRT 826 (for J.S.L.); 4) Cephalon, Inc.

\section{References}

1. Schwartz JC, Pollard H, and Quach TT, Histamine as a neurotransmitter in mammalian brain: neurochemical evidence. J Neurochem 35: 26-33, 1980.

2. Haas $\mathrm{HL}$ and Panula $\mathrm{P}$, The role of histamine and the tuberomammillary nucleus in the nervous system. Nat Rev Neurosci 2003, 4: 121-130.

3. Brown RE, Stevens DR, and Haas HL, The physiology of brain histamine. Prog Neurobiol 63: 637672, 2001.

4. Lin JS, Brain structures and mechanisms involved in the control of cortical activation and wakefulness, with emphasis on the posterior hypothalamus and histaminergic neurons. Sleep Med. Rev. 4: 471-503, 2000.

5. Moruzzi G, The sleep-waking cycle. Ergeb Physiol 64: 1-165, 1972.

6. Sakai K, El Mansari M, Lin JS, Zhang JG, and Vanni-Mercier G, The posterior hypothalamus in the regulation of wakefulness and paradoxical sleep. In: The Diencephalon and Sleep,(Eds. Mancia M and Marini G), pp. 171-198. Raven Press, New York, 1990.

7. Steriade M, Alertness, quiet sleep, dreaming. In: Cerebral Cortex, Vol.9 (Peters A ed), pp. 279-357, New York: Plenum Pub.. 1991

8. McCormick DA. Neurotransmitter actions in the thalamus and cerebral cortex and their role in neuromodulation of thalamocortical activity. Prog Neurobiol 39: 337-388.1992

9. Jones BE, Arousal systems, Front. Biosci. 1;8:s438-451, 2003

10. Panula $P$, Yang HY, and Costa E, Histamine-containing neurons in the rat hypothalamus. Proc Natl Acad Sci U S A 81: 2572-2576, 1984.

11. Watanabe T, Taguchi $Y$, Shiosaka S, Tanaka J, Kubota H, Terano Y, Tohyama M, and Wada H, Distribution of the histaminergic neuron system in the central nervous system of rats; a fluorescent immunohistochemical analysis with histidine decarboxylase as a marker. Brain Res 295: 13-25, 1984.

12. Lin JS, Luppi PH, Salvert D, Sakai K, and Jouvet M, Histamine-immunoreactive neurons in the hypothalamus of cats. C R Acad Sci III 303: 371-376, 1986.

13. Lin JS, Hou $Y$, Sakai K, and Jouvet M, Histaminergic descending inputs to the mesopontine tegmentum and their role in the control of cortical activation and wakefulness in the cat. J Neurosci 16: 1523-1537, 1996.

14. Takahashi K, Lin J. S., and Sakai K. Neuronal activity of histaminergic tuberomammillary neurons during wake-sleep states in the mouse. J Neurosci . 26(40):10292-10298, 2006

15. Vanni-Mercier G, Gigout S, Debilly G, and Lin JS, Waking selective neurons in the posterior hypothalamus and their response to histamine H3-receptor ligands: an electrophysiological study in freely moving cats. Behav.Brain Res. 144: 227-241, 2003. 
16. Parmentier R, Ohtsu H, Djebbara-Hannas Z, Valatx JL, Watanabe T, and Lin JS, Anatomical, physiological, and pharmacological characteristics of histidine decarboxylase knock-out mice: evidence for the role of brain histamine in behavioral and sleep-wake control. J Neurosci 22: 7695$7711,2002$.

17. Crochet $S$ and Sakai $K$, Effects of microdialysis application of monoamines on the EEG and behavioural states in the cat mesopontine tegmentum. Eur J Neurosci 11: 3738-3752, 1999.

18. Arrang JM, Garbarg M, and Schwartz JC, Auto-inhibition of brain histamine release mediated by a novel class (H3) of histamine receptor. Nature 302: 832-837, 1983.

19. Arrang JM, Garbarg M, and Schwartz JC, Autoinhibition of histamine synthesis mediated by presynaptic H3-receptors. Neuroscience 23: 149-157, 1987.

20. Lin JS, Sakai K, Vanni-Mercier G, Arrang JM, Garbarg M, Schwartz JC, and Jouvet M, Involvement of histaminergic neurons in arousal mechanisms demonstrated with H3-receptor ligands in the cat. Brain Res 523: 325-330, 1990.

21. Monti JM, Jantos H, Boussard M, Altier H, Orellana C, Olivera S. Effects of selective activation or blockade of the histamine $\mathrm{H}_{3}$-receptor on sleep and wakefulness. Eur J Pharmacol; 205:283-287, 1991

22. McLeod RL, Aslanian R, del PM, Duffy R, Egan RW, Kreutner W, McQuade R, and Hey JA, SCH 50971, an orally active histamine H3 receptor agonist, inhibits central neurogenic vascular inflammation and produces sedation in the guinea pig. J Pharmacol Exp Ther 287: 43-50, 1998.

23. Lamberty $Y$, Margineanu DG, Dassesse $D$, and Klitgaard $H, H 3$ agonist immepip markedly reduces cortical histamine release, but only weakly promotes sleep in the rat. Pharmacol Res 48: 193-198, 2003.

24. Hancock, A.A. The challenge of drug discovery of a GPCR target: analysis of preclinical pharmacology of histamine $\mathrm{H}_{3}$ antagonists/inverse agonists. Biochem Pharmacol 2006, 71:11031113.

25. Bastuji $\mathrm{H}$ and Jouvet $\mathrm{M}$, Successful treatment of idiopathic hypersomnia and narcolepsy with modafinil. Prog Neuropsychopharmacol Biol Psychiatry 1988, 12: 695-700.

26. US Modafinil in Narcolepsy Multicenter Study Group. Randomized trial of modafinil for the treatment of pathological somnolence in narcolepsy. Ann. Neurol. 1998, 43, 88-97.

27. US Modafinil in Narcolepsy Multicenter Study Group. Randomized trial of modafinil for the treatment for the excessive daytime somnolence of narcolepsy. Neurol. 54, 1166-1175, 2000.

28. Cziesler, CA, Walsh JK, Roth, T. Hughes RJ, Wright, KP, Kingsbury, L., Arora, S Schwartz JRL, Niebler, GE. Dinges, DF for the U.S. Modafinil in Shift Work Sleep Disorder Study Group. Modafinil for excessive sleepiness associated with shift-work sleep disorder. New Eng. J. Med. 353, 476 486, 2005.

29. Schwartz JC, Arrang JM, Garbarg M, Pollard H, and Ruat M, Histaminergic transmission in the mammalian brain. Physiol Rev 1991, 71: 1-51, 1991. 
30. Ligneau X, Lin J, Vanni-Mercier G, Jouvet M, Muir JL, Ganellin CR, Stark H, Elz S, Schunack W, and Schwartz J, Neurochemical and behavioral effects of ciproxifan, a potent histamine H3-receptor antagonist. J Pharmacol Exp Ther 1998, 287: 658-666.

31. Mignot, E,, Nishino, S. Gulleminault C. and Dement W.C. Modafinil binds to the dopamine uptake carrier site with lower affinity. Sleep, 1994, 17, 436-437.

32. Wisor JP, Nishino S, Sora I, Uhl GH, Mignot E, and Edgar DM, Dopaminergic role in stimulantinduced wakefulness. J Neurosci 2001, 21: 1787-1794.

33. Madras BK, Xie Z, Lin Z, Jassen A, Panas H, Lynch L, Johnson R, Livni E, Spencer TJ, Bonab AA, Miller GM, Fischman AJ Modafinil occupies dopamine and norepinephrine transporters in vivo and modulates the transporters and trace amine activity in vitro. J. Pharmacol. Exp. Ther. 2006, 319, 561-569.

34. Leurs $\mathrm{R}$, Bakker RA, Timmerman $\mathrm{H}$, and de Esch, I, The histamine $\mathrm{H}_{3}$ receptor: from gene cloning to $\mathrm{H}_{3}$ receptor drugs. Nat Rev Drug Discov 4: 107-120, 2005.

35. Lin JS, Roussel B, Akaoka H, Fort P, Debilly G, and Jouvet M, Role of catecholamines in the modafinil and amphetamine induced wakefulness, a comparative pharmacological study in the cat. Brain Res 591: 319-326, 1992.

36. Lin JS, Gervasoni D, Hou Y, Vanni-Mercier G, Rambert F, Frydman A, and Jouvet M, Effects of amphetamine and modafinil on the sleep/wake cycle during experimental hypersomnia induced by sleep deprivation in the cat. J Sleep Res 9: 89-96, 2000.

37. Touret M, Sallanon-Moulin M, and Jouvet M, Awakening properties of modafinil without paradoxical sleep rebound: comparative study with amphetamine in the rat. Neurosci Lett 189: 43-46, 1995.

38. Edgar DM and Seidel WF, Modafinil induces wakefulness without intensifying motor activity or subsequent rebound hypersomnolence in the rat. J Pharmacol Exp Ther. 1997, 283: 757-769.

39. Cirelli C, How sleep deprivation affects gene expression in the brain: a review of recent findings. J Appl Physiol 92: 394-400, 2002.

40. Cirelli C, Faraguna U, and Tononi G, Changes in brain gene expression after long-term sleep deprivation. J Neurochem 98: 1632-1645, 2006.

41. Scammell TE, Estabrooke IV, McCarthy MT, Chemelli RM, Yanagisawa M, Miller MS, and Saper $\mathrm{CB}$, Hypothalamic arousal regions are activated during modafinil-induced wakefulness. J Neurosci 20: 8620-8628, 2000

42. Ishizuka $T$, Sakamoto $Y$, Sakurai $T$, and Yamatodani $A$, Modafinil increases histamine release in the anterior hypothalamus of rats. Neurosci Lett 339: 143-146, 2003.

43. Pompeiano $M$, Cirelli $C$, and Tononi $G$, Immediate-early genes in spontaneous wakefulness and sleep: expression of c-fos and NGFI-A mRNA and protein. J Sleep Res 3: 80-96, 1994.

44. Pompeiano M, Cirelli C, Arrighi $\mathrm{P}$, and Tononi G, C-Fos expression during wakefulness and sleep. Neurophysiol.Clin 25: 329-341, 1995.

45. Sastre JP, Buda C, Lin JS, and Jouvet M, Differential c-fos expression in the rhinencephalon and striatum after enhanced sleep-wake states in the cat. Eur J Neurosci 12: 1397-1410, 2000. 
46. Tanganelli S, Perez dIM, Ferraro L, Mendez-Franco J, Beani L, Rambert FA, and Fuxe K, Modafinil and cortical gamma-aminobutyric acid outflow. Modulation by 5 -hydroxytryptamine neurotoxins. Eur J Pharmacol 273: 63-71, 1995.

47. Ferraro, L., Tanganelli, S., O'Connor, W. T., Antonelli, T, Rambert, F., Fuxe, K. The vigilance promoting drug modafinil decreases GABA release in the medial preoptic area and in the posterior hypothalamus of the awake rat: possible involvement of the serotonergic 5-HT3 receptor, Neurosci. Lett., 220: 5-8, 1996.

48. Lin JS, Parmentier R., Valatx J. L., and Watanabe T. Cortical EEG and sleep-wake cycle in histamine H1-receptor knockout mice. Soc. Neurosci. Abstr. 2002, 32nd Annual Meeting, Orlando, $\mathrm{FL} \# 474.8$

49. Dugovic C, Koehl M, Rontal AD, Toyota H, Lovenberg TW, and Turek FW, Sleep in mice lacking the histamine $\mathrm{H}_{3}$ receptor, a putative genetic animal model for REM sleep behavior disorder. Sleep 25 suppl: A114, 2002.

50. Toyota H, Dugovic C, Koehl M, Laposky AD, Weber C, Ngo K, Wu Y, Lee DH, Yanai K, Sakurai E, Watanabe T, Liu C, Chen J, Barbier AJ, Turek FW, Fung-Leung WP, and Lovenberg TW, Behavioral characterization of mice lacking histamine $\mathrm{H}(3)$ receptors. Mol Pharmacol 62: 389-397, 2002.

51. Ohtsu H, Tanaka S, Terui T, Hori Y, Makabe-Kobayashi Y, Pejler G, Tchougounova E, Hellman L, Gertsenstein M, Hirasawa N, Sakurai E, Buzas E, Kovacs P, Csaba G, Kittel A, Okada M, Hara M, Mar L, Numayama-Tsuruta K, Ishigaki-Suzuki S, Ohuchi K, Ichikawa A, Falus A, Watanabe T, and Nagy A, Mice lacking histidine decarboxylase exhibit abnormal mast cells. FEBS Lett 502: 53-56, 2001.

52. Chu M, Huang ZL, Qu WM, Eguchi N, Yao MH, and Urade Y, Extracellular histamine level in the frontal cortex is positively correlated with the amount of wakefulness in rats. Neurosci Res 49: 417420, 2004.

53. Lin JS, Hou Y, and Jouvet M, Potential brain neuronal targets for amphetamine-, methylphenidate-, and modafinil-induced wakefulness, evidenced by c-fos immunocytochemistry in the cat. Proc Natl Acad Sci U S A 93: 14128-14133, 1996.I

54. Inoue I, Yanai K, Kitamura D, Taniuchi I, Kobayashi T, Niimura K, and Watanabe T, Impaired locomotor activity and exploratory behavior in mice lacking histamine $\mathrm{H}_{1}$ receptors. Proc Natl Acad Sci U S A 93: 13316-13320, 1996.

55. Kobayashi T, Tonai S, Ishihara Y, Koga R, Okabe S, and Watanabe T, Abnormal functional and morphological regulation of the gastric mucosa in histamine $\mathrm{H}_{2}$ receptor-deficient mice. J Clin Invest 105: 1741-1749, 2000

56. Takahashi $K$, Suwa $H$, Ishikawa $T$, and Kotani $H$, Targeted disruption of $\mathrm{H}_{3}$ receptors results in changes in brain histamine tone leading to an obese phenotype. J Clin Invest 110: 1791-1799, 2002.

57. Esbenshade TA, Krueger KM, Miller TR, Kang CH, Denny LI, Witte DG, Yao BB, Fox GB, Faghih R, Bennani YL, Williams $M$, and Hancock AA, Two novel and selective nonimidazole histamine $\mathrm{H}_{3}$ 
receptor antagonists A-304121 and A-317920: I. In vitro pharmacological effects. J Pharmacol Exp Ther 305: 887-896, 2003.

58. Gbahou F, Vincent L, Humbert-Claude M, Tardivel-Lacombe J, Chabret C, and Arrang JM, Compared pharmacology of human histamine $\mathrm{H}_{3}$ and $\mathrm{H}_{4}$ receptors: structure-activity relationships of histamine derivatives. Br J Pharmacol 147: 744-754, 2006.

59. Nishino S, Fujiki N, Ripley B, Sakurai E, Kato M, Watanabe T, Mignot E, Yanai K, Decreased brain histamine content in hypocretin/orexin receptor-2 mutated narcoleptic dogs. Neurosci Lett 313:125128, 2001

60. Mignot E, Nishino S. Emerging therapies in narcolepsy-cataplexy. Sleep $28: 754-763,2005$

61. Hancock AA and Fox GB, Perspectives on cognitive domains, $\mathrm{H}_{3}$ receptor ligands and neurological disease. Expert.Opin Invest Drugs 13: 1237-1248, 2004.

62. Passani MB, Lin JS, Hancock A, Crochet $S$, and Blandina $P$, The histamine $\mathrm{H}_{3}$ receptor as a novel therapeutic target for cognitive and sleep disorders. Trends Pharmacol Sci 25: 618-625, 2004.

63. Ligneau X, Perrin D, Landais L, Camelin J-C., Calmels TPG, Berrebi-Bertrand I, Lecomte J-M, Parmentier R, Ancalet, C., Lin J-S, Bertaina-Anglade C, Dtieu la Rochelle F, d'Aniello F, Rouleau A, Gbahou F, Arrang J-M, Ganellin CR, Schunack W, Schwartz, J-C., BF2.649, a non-imidazole inverse agonist/antagonist at human histamine $\mathrm{H}_{3}$ receptor : preclinical pharmacology. J Pharmacol Exp Ther doi :10:1124/jpet.106.111039, 2006.

64. Bonaventure P, Letavic M, Dugovic C, Alusio L, Pudiak C, Lord B, Mazur C, Kamme F, Nishino S, Carruthers $\mathrm{N}$, Lovenberg $\mathrm{T}$, Histamine $\mathrm{H}_{3}$ Receptor Antagonists: From target identification to drug leads. Biochem Pharmacol, this issue. 
Table 1. Effect of wake-promoting compounds as indicated, on cumulated wake $(\mathrm{CW})$ amount during $4 \mathrm{~h}$ and on latencies to slow wave sleep (SWS) and paradoxical sleep (PS). Compounds were administered in methylcellulose $0.25 \%$ i.p. at 11.30 (light phase). The results are expressed both as the mean time ( $\min \pm$ SEM) spent in waking (W) or to sleep onset, and as a percentage (in parentheses) obtained from the ratio of mean experimental values (compound treatment) over the mean control values (saline injection of the same animals). In the latter case, $100 \%$ indicates the control level or no change. Note that all compounds induce a dose-dependent increase in waking and concomitant delayed sleep latency $\left({ }^{*},{ }^{* *} p<0.05,0.01\right.$; Dunnett's $t$ test as compared with placebo; $n=8$ ).

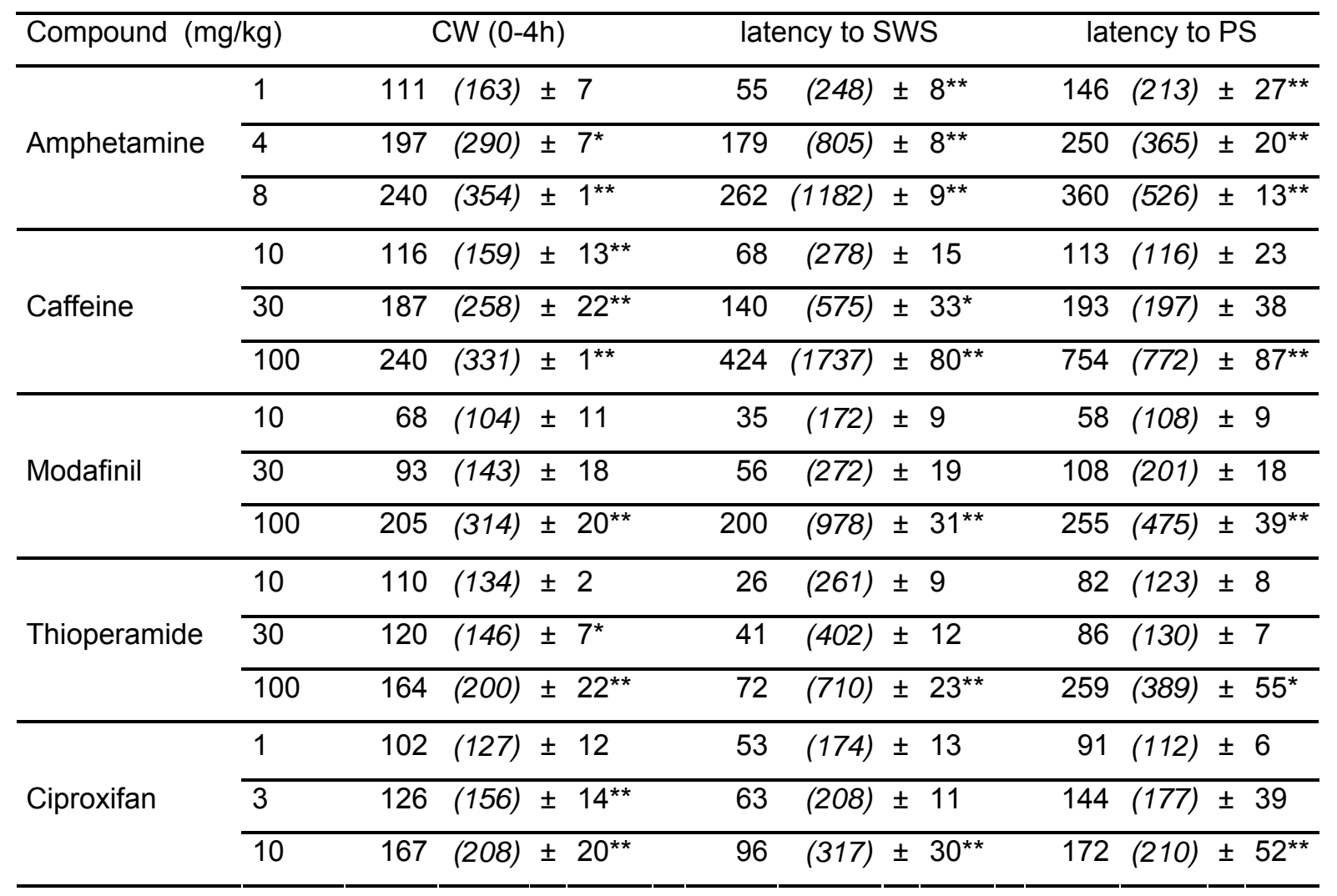


Table 2. Slow wave sleep (SWS) amount (min \pm SEM) during periods of significant arousal, immediate recovery and different recovery periods following wake-promoting compounds given i.p. at $11 \mathrm{~h} 30$ (light phase), as indicated. The duration of each period is compound- and dose-dependent and was determined individually. The last post-injection period between $17-19 \mathrm{~h}$ corresponds to a spontaneous awakening period seen with C57/Black6 strain just before lights-on at baseline recordings. In parentheses are percentages of SWS duration compared with those obtained with placebo in the same animals. $100 \%$ signifies the control level or no change. Note 1) a dose-dependant SWS-suppressing effect of all compounds; 2) the presence of sleep rebound during different recovery periods after amphetamine or caffeine 3 ) the absence of sleep rebound during any recovery period after modafinil, thioperamide or ciproxifan dosing $\left({ }^{*},{ }^{* *} p<0.05,0.01\right.$; Dunnett's $t$ test as compared with placebo; $n=8$ )

\section{Compound \&}

dose $(\mathrm{mg} / \mathrm{kg})$

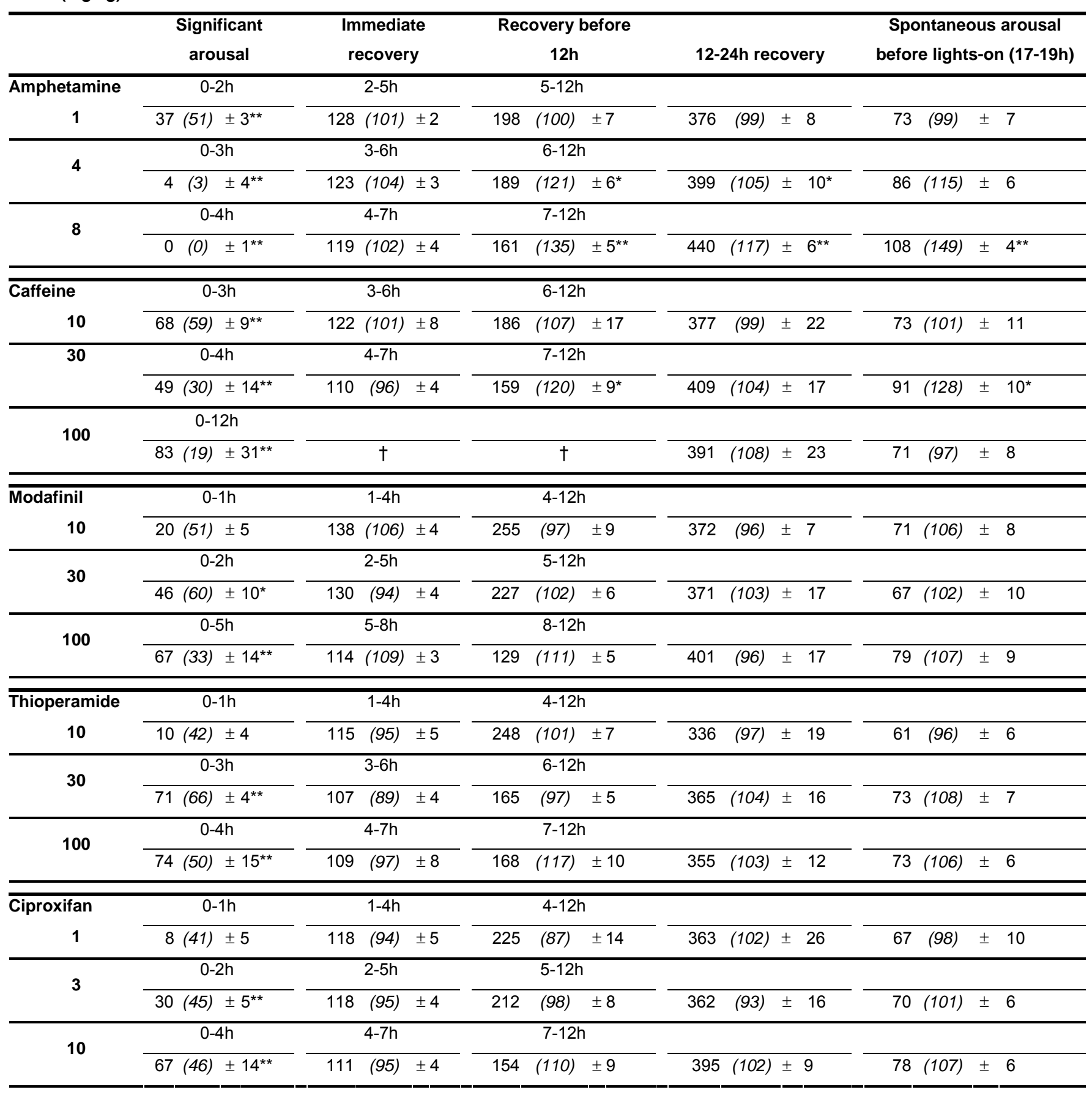


Table 3. Effects of amphetamine, modafinil and ciproxifan on wake amount in wild type and knockout mouse models. The results are expressed either as the mean time ( $\min \pm$ SEM) spent awake, or as a percentage (in parentheses) obtained from the ratio of mean experimental values (compound treatment, i.p.) over the mean control values (saline injection) in the same animals. $100 \%$ indicates control level or no change. Three analyzed periods of $4 \mathrm{~h}$ are shown. Note that 1 ) amphetamine and modafinil increase waking in both $\mathrm{HDC}^{-1-}$ and $\mathrm{HDC}^{+/+}$mice; 2) ciproxifan elicits significant waking effect in all wild type models and $\mathrm{H}^{-/-}$mice but not in $\mathrm{HDC}^{-/-}$or $\mathrm{H}^{-/-}$mice; 3) a significant sleep rebound was seen only with amphetamine, and not with other compounds, in both $\mathrm{HDC}^{-/}$and $\mathrm{H}^{-/-}$mice $\left({ }^{\circ} \mathrm{p}>0.05\right.$; ${ }^{* *}$, ${ }^{* * *} \mathrm{p}<0.01,0.001$; Student's $\mathrm{t}$ test as compared with placebo (individual animal served as its own control) or between knock-out and wild type mice).

Time post-injection

\begin{tabular}{|c|c|c|c|c|c|c|c|c|c|c|c|c|c|}
\hline \multirow{3}{*}{$\begin{array}{c}\text { Amphetamine } \\
(1 \mathrm{mg} / \mathrm{kg})\end{array}$} & \multirow{3}{*}{\multicolumn{2}{|c|}{$\begin{array}{l}\text { Genotype } \\
\text { HDC +/+ } \\
\text { HDC -/- }\end{array}$}} & \multicolumn{2}{|c|}{$0-4 \mathrm{~h}$} & & \multicolumn{4}{|c|}{$4-8 h$} & \multicolumn{4}{|c|}{$8-12 h$} \\
\hline & & & 135 (150) & $\pm 7^{* * *}$ & 70 & 68 & (91) & \pm & 7 & 141 & (79) & \pm & $9^{*}$ \\
\hline & & & 127 (139) & $\pm 7^{* \star *}$ & & 70 & (94) & \pm & 5 & 138 & (77) & & $10^{*}$ \\
\hline \multirow{2}{*}{$\begin{array}{l}\text { Modafinil } \\
(32 \mathrm{mg} / \mathrm{kg})\end{array}$} & $\mathrm{HDC}+/+$ & \multirow{2}{*}{$\mathrm{n}=7$} & 159 (185) & $\pm 9^{* *}$ & o & 77 & (104) & & 6 & 162 & (93) & \pm & \\
\hline & HDC -/- & & 166 (200) & $\pm 11^{\star \star \star}$ & & 70 & (92) & \pm & 3 & 178 & (107) & \pm & 8 \\
\hline \multirow{8}{*}{$\begin{array}{c}\text { Ciproxifan } \\
(1 \mathrm{mg} / \mathrm{kg})\end{array}$} & $\mathrm{HDC}+/+$ & \multirow{2}{*}{$n=9$} & 107 (178) & $\pm 7^{* * *}$ & \multirow{2}{*}{$7^{* * *}$} & 70 & (94) & \pm & 5 & 145 & (102) & \pm & 7 \\
\hline & HDC -/- & & 68 (107) & $\pm 6^{\circ}$ & & 75 & (96) & \pm & 4 & 125 & (102) & \pm & 9 \\
\hline & $\mathrm{H} 1+/+$ & \multirow{2}{*}{$\mathrm{n}=8$} & 113 (186) & $\pm 6^{* \star *}$ & \multirow[t]{2}{*}{$7^{* * *}$} & 78 & (102) & \pm & 8 & 179 & (101) & \pm & 8 \\
\hline & H1 -/- & & 70 (103) & $\pm 8^{\circ}$ & & 74 & (105) & \pm & 5 & 161 & (99) & \pm & 8 \\
\hline & $\mathrm{H} 2+/+$ & \multirow{2}{*}{$n=8$} & 116 (185) & $\pm 11^{\star * *}$ & \multirow[t]{2}{*}{$7 \circ$} & 65 & (94) & \pm & 8 & 171 & (110) & \pm & 12 \\
\hline & H2 -/- & & 105 (193) & $\pm 9^{* * *}$ & & 69 & (104) & \pm & 5 & 168 & (102) & \pm & 10 \\
\hline & $\mathrm{H} 3+/+$ & $\mathrm{n}=$ & 111 (150) & $\pm 7^{* *}$ & \multirow[t]{2}{*}{$7^{* *}$} & 67 & (91) & \pm & 4 & 156 & (107) & \pm & \\
\hline & H3 -/- & 12 & $72 \quad(98)$ & $\pm 4^{\circ}$ & & 76 & (97) & \pm & 2 & 149 & (105) & \pm & 6 \\
\hline
\end{tabular}




\section{Legends to figures}

Figure 1. Effects of wake promoting compounds on cortical EEG and sleep-wake states in mice. Typical examples of polygraphic recordings, cortical EEG power density $\left(\mu \mathrm{V}^{2}\right)$ in $\delta$ band $(0.8-5 \mathrm{~Hz})$ and cortical fast rhythms $(\beta+\gamma, 30-60 \mathrm{~Hz})$, illustrating the waking state induced by intraperitoneal injection of amphetamine, modafinil and ciproxifan at doses indicated. Note that all compounds induce a suppression of cortical slow activity $(0.5-8 \mathrm{~Hz})$ accompanied with a continuous cortical fast rhythms $(30-60 \mathrm{~Hz})$, whereas only ciproxifan causes a marked enhancement of the fast rhythm amplitude. EEG, electroencephalogram; EMG, electromyogram; PS, paradoxical sleep; SWS, slow wave sleep; W, wake.

Figure 2. Hourly wake amount during $9 \mathrm{~h}$ following intraperitoneal injection (11:30 a.m. light phase) of increasing doses of wake promoting agents in C57/Black6/J mice. Note that the duration of waking effect induced by all compounds is dose-related $\left({ }^{*},{ }^{* *} p<0.05,0.01\right.$; Student's $t$ test as compared with placebo (methylcellulose $0.25 \%) ; n=8$ ).

Figure 3. Typical examples of polygraphic recordings, cortical EEG power spectral density $\left(\mu \mathrm{V}^{2}\right)$ in different frequency bands and corresponding hypnograms illustrating the effects of intraperitoneal injection of imetit (at $18 \mathrm{~h}$, indicated by the arrow) on the EEG and sleep-wake cycle in a mouse. Note that compared with the use of placebo, the compound enhances markedly cortical slow activity $(0.8-5 \mathrm{~Hz}, \delta$ and slow $\Theta)$ and decreases fast rhythms $(\beta+\gamma, 30-60 \mathrm{~Hz})$, accompanied with an increase in slow wave sleep (SWS) (EEG, electroencephalogram; EMG, electromyogram; PS, paradoxical sleep; W, wake).

Figure 4. Effects of co-administration of ciproxifan with imetit on the sleep-wake cycle and latencies to slow wave sleep (SWS) and paradoxical sleep (PS) in the mouse. Representative 6h hypnograms and histograms showing that 1) the waking effect of ciproxifan injection (i.p. at $11 \mathrm{~h} 30$ indicated by the first arrow) is reversed by increasing doses of imetit (i.p. at $12 \mathrm{~h}$, indicated by the second arrow); 2) the prolonged latency to SWS caused by ciproxifan is reversed by imetit at large doses while that to PS remained unchanged. Ordinates: sleep-wake stages. ( ${ }^{*} \mathrm{p}<0.05$; Dunnett's $t$ test after significant ANOVA, $n=8$ ).

Figure 5. Quantitative variations of the sleep-wake cycle following administration of imetit alone or coupled with ciproxifan (i.p. dosing at $12 \mathrm{~h}$, light phase). Histograms showing mean time (min) spent in each sleepwake stage during $4 \mathrm{~h}$ after compound administration. Note 1 ) in top panel, that imetit dosing (i.p., at $18 \mathrm{~h}$ just before the lights-off phase or waking period) caused a dose-related decrease in waking (W) and an increase in slow wave sleep (SWS) without reducing paradoxical sleep (PS); 2) in lower panel, ciproxifan (i.p., at $11 \mathrm{~h} 30$ during light phase or sleeping period) caused a significant increase in W and a decrease in SWS; 3 ) in lower panel, the $W$-increasing and SWS-decreasing effects of ciproxifan were attenuated significantly by larger doses of imetit (i.p. at 12h), namely 3 and $10 \mathrm{mg} / \mathrm{kg}$. PS remains decreased although statistically non significant. ( ${ }^{*} p<0.05$; Dunnett's $t$ test after significant ANOVA; $\left.n=8\right)$.

Figure 6. Effects of modafinil on cortical EEG and sleep-wake states in wild type (HDC+/+, upper traces) and histidine decarboxylase knockout (HDC-/-, lower traces) mice. Examples of polygraphic recordings, cortical EEG power spectral density $\left(\mu \mathrm{V}^{2}\right)$ in different frequency bands, and the corresponding hypnograms illustrating, in both genotypes, an identical awakening effect of modafinil (32 mg/kg, in 20\% DMSO, i.p., 10:00 as indicated by arrow) accompanied with a suppression of cortical slow activity (0.8-5 Hz) and continuous 
cortical fast rhythms (30-60 Hz). EEG, electroencephalogram; EMG, electromyogram; PS, paradoxical sleep; SWS, slow wave sleep; W, wake.

Figure 7. Effects of amphetamine, modafinil and ciproxifan on the sleep-wake states during $4 \mathrm{~h}$ in wild type (HDC+/+, upper) and histidine-decarboxylase knockout (HDC-/-, bottom) mice. Note that amphetamine or modafinil dosing (i.p.) produced a similar increase in waking (W) and a concomitant decrease in slow wave sleep (SWS) and paradoxical sleep (PS) in both mouse genotypes and that ciproxifan increased waking and decrease SWS and PS in HDC+/+ mice, but had no effect in HDC-/-mice. ${ }^{*},{ }^{* *}$, ${ }^{* * *} p<0.05,0.01,0.001$ respectively, Student's t test as compared with control. 